\title{
Organizational and Financial Principles for the Development of Euroregions
}

\author{
Submitted 09/02/20, $1^{\text {st }}$ revision 10/04/19, $2^{\text {nd }}$ revision 13/05/19, accepted 20/07/20 \\ Iaroslav V. Petrunenko ${ }^{1}$, Svitlana I. Belei ${ }^{2}$, Maryna V. Petchenko ${ }^{3}$, \\ Nataliia V. Kovalenko ${ }^{4}$, Olena A. Bodnar ${ }^{5}$, Nataliia G. Maslak ${ }^{6}$
}

\begin{abstract}
:
Purpose: Expanding the borders of international trade, along with the implementation of European policy "without borders" for stimulating economic and social development countries put forward demands for ensuring growth and border areas. One of the forms of such incentives is the formation of Euroregions from two or more territories of different countries. As a result, such a process revitalizes cross-border cooperation and helps eliminate the existing imbalances in economic growth. Thus, the purpose of this academic paper is to identify and analyze the organizational and financial characteristics of the development of Euroregions at the modern stage.

Design/Methodology/Approach: We have used the method of comparison, graphical method, as well as the method of analysis and synthesis to conduct the research.

Findings: This outlined goal has been ensured through the allocation of legal forms of Euroregions' activities the conclusion of an agreement on cooperation, the creation of private associations for cross-border purposes, as well as organizations endowed with legal capacity. At the same time, we have analyzed the financial incentives for the implementation of programs and projects, through the allocation of additional funding from European funds.

Originality/Value: The paper has identified the most popular forms and directions of the Euroregions' activities, as well as outlining the problems that they come across along with determining ways to solve them.
\end{abstract}

Keywords: Financial incentives, legal form of activity, cooperation types of Euroregions.

JEL Codes: M21, O10, O50, F50.

Article Type: Research paper.

\footnotetext{
${ }^{1}$ Associate professor, National University “Odesa Law Academy”, petrunenko@email.ua

${ }^{2}$ Associate professor, Yuriy Fedkovych Chernivtsi National University, s.belei@chnu.edu.ua

${ }^{3}$ Head of the Research Department, Kremenchuk College of Aviation of the Kharkiv National University of Internal Affairs, marinapetcenko@gmail.com

${ }^{4}$ Associate professor, Kharkiv Regional Institute of Public Administration of the National Academy of Public Administration under the President of Ukraine, nkovalenko2008@ukr.net ${ }^{5}$ Associate professor, Mykolayiv National Agrarian University, bodnarolena1606@gmail.com

${ }^{6}$ Associate professor, Sumy National Agrarian University, n.maslak@ukr.net
} 


\section{Introduction}

The expansion of international trade borders has necessitated the search for new forms of cooperation between countries. Consequently, cross-border cooperation arises as an effective tool aimed at establishing close partnerships between the border areas of neighboring countries in order to stimulate their development. The practice of functioning within European Union of such institutional form as the Euroregions is the closest and most effective form of interaction between the regions of different countries. As a result, border areas receive additional opportunities for development in all directions of the geographical space, in contrast to the regions that operate within centralized political systems, for as much as the latter, on the contrary, have the possibility to develop inside the country, which often results in the transformation of the border area into a socially and economically limited zone. The trends specified are taking place alongside the dissemination of the policy of European Union (EU) and Council of Europe on the formation of "Europe without dividing borders", on the way to reducing disparities in territorial development of regions and ensuring equalization between them, which in the aggregate determines the high relevance of the investigation's topic.

\section{Literature Review}

The study of the available scientific literature on the creation and functioning of Euroregions, makes it possible to form a statement that this topic has become widespread among both world scientists and international institutions. In particular, Roper (2007) and Zapletalová (2005) in their researches have revealed the features of the functioning of border areas, from the standpoint of their limitations due to transport accessibility, spatial barriers, unfavorable demographic structure, which in the aggregate has resulted in the underdevelopment of these areas.

In addition, Akimova et al. (2020), emphasize: "The problems of ensuring sustainable development of territories have become very important in the context of the transformation of modern economic systems into the global economic space. At the same time, it should be noted that every country in the world often provides support for the social-economic development of individual territories (regions)". Along with this, Krätke (2002) has believed that the development of cross-border cooperation is the solution to disparities in the development of individual territories. Lepik (2009) in her study, considering the role of Euroregions in the economy of the Baltic States, has noted that Euroregions are administrative-territorial structures, and their purpose is to stimulate cross-border cooperation between local and regional authorities of different countries, located at the boundary of state borders.

It has been noted, that the Euroregions (2010) represent a transactional structure of cooperation between at least two territories of different countries of European Union or Europe. Herewith, the basic goal of cooperation is to promote the common interests of the population of the border lands (Cekhanovich, 2019). At the same 
time, Noferini et al. (2020), studying the current realities of the functioning of the Euroregions, have noted that the existence of this form of cross-border cooperation is a consolidating reality. Next to the foregoing, Gretta and Otto (2019), have considered the features of the functioning of the Euroregions from the perspective of their multifunctionality through the prism of analyzing the value of the Association of European Border Regions (AEBR) as the highest representative body of the Euroregions.

\section{Data and Methods}

Methods of analysis and synthesis, comparison and graphical method have been used to study the statistical data presented in the academic paper. In particular, the analysis of the number of Euroregions from the moment of the formation of the first of them till present time was carried out by applying the analysis and synthesis method, the structure of all Euroregions depending on their legal form has been reflected by using a graphical method. In addition, the methods of systematization, grouping and logical generalization have been applied in the academic paper for systematization of information, the formation of sound conclusions and proposals.

Descriptive statistical methods (average values, minimum and maximum values, correlation) have been used to determine the dependence of financing of the Nordic region in 2000-2018 and the economic growth of the region. The time-series data of the indicators for 2000-2018 have been used to determine the strength and direction of the interconnection between the input and output flows of foreign direct investment in the Nordic region, net borrowing, and the growth rate of real GDP in the region. The correlation coefficients and the Granger causality test with a lag of 2 years have been chosen as a tool for assessing the interconnection and determining cause-effect relations between the variables.

\section{Results of the Study}

Currently, the Euroregions play an important role in creating favorable conditions for the development of European Union along its external borders, especially the countries of Central and Eastern Europe. An analysis of the activities of the Euroregions shows that such border associations are currently the most common form of cross-border cooperation between European countries. The members of the Euroregions are mainly regional and municipal entities or their associations. However, according to foreign experts' assessment, the Euroregions are not able to work effectively in case of absence of interstate agreements on cross-border cooperation between the interested countries.

Historically, the formation of the Euroregions was conditioned by the need to overcome unnatural barriers between different border regions and ethnic groups, which were geographically located nearby. Residents of these areas often use crossborder cooperation as a means to overcome existing problems and improve living 
conditions. It follows herefrom that Euroregions can function successfully at all levels of development. Cooperation within the formed Euroregions usually begins with exchanges between people and the implementation of cultural programs. Then, the interaction between the members of the Euroregions steadily grows, differentiating and branching (Lepik, 2009). Thus, according to the data (Lepik, 2009), the types of cooperation in the Euroregion vary depending on the source of initiation of cooperation, the level of their development and direction. In particular, cooperation may be initiated by local and regional authorities, in the process of their cooperation in neighboring regions or along common borders, as well as between the participants, including national authorities in the process of cross-border cooperation.

In addition, the solution to the problems of common borders is conducted within the Euroregion, as well as the order of cooperation in case of emergency, areas of cooperation between law enforcement agencies, migration of the population of border regions, etc. Along with this, if a member state of European Union is part of the Euroregion, it receives additional funding from Brussels, part of which is also allocated by partners in the Euroregion, and acts as an additional incentive for interregional cooperation of European countries. Attraction of foreign investment is one of the financing tools in the region. The application of such instruments of financial incentive of Euroregions' formation and development has led to a positive dynamics in their quantity. Therefore, let's analyze the trend of changes in the number of Euroregions by using Figure 1.

Thus, analyzing the data shown in Figure 1, we can observe that the largest increase in the formation of Euroregions falls in the period from 1990 to 2010, where the total number of formed Euroregions is 40. During the period from 2010 till present time, 20 more regions have joined the general list of Euroregions, which is positive dynamics, as much as the volumes of cross-border cooperation are growing, which positively affects the economies of the countries involved in this process.

Figure 1. Dynamics of change in the number of Euroregions for 1970-2020 
For instance, let's consider the Euroregion Nordic Region (Nordic cooperation, n./d.a), created in 1952 (which involves Denmark, Iceland, Finland, Norway, the Faroe Islands, Sweden, Greenland and Åland), its economic indicators, the state of funding (Figure 2). The Scandinavian model of functioning of the Euroregion is characterized by a high level of taxation, financing from the budgets of the Nordic countries in order to ensure social protection. High taxes contributed to a low level of borrowing in the Nordic Region. From 2000 to 2007, economic growth in the Nordic Region was stable; in 2008-2009 the region was characterized by an economic downturn, a decline in foreign investment in the region, however, incoming investment has always been positive (Figure 2). This has a positive effect on the development of the Nordic Region.

Figure 2. Dynamics of Average Foreign direct investment in Nordic region's countries (in percent of GDP) and Nordic region Real gross domestic product annual growth, \% in 2000-2018

15

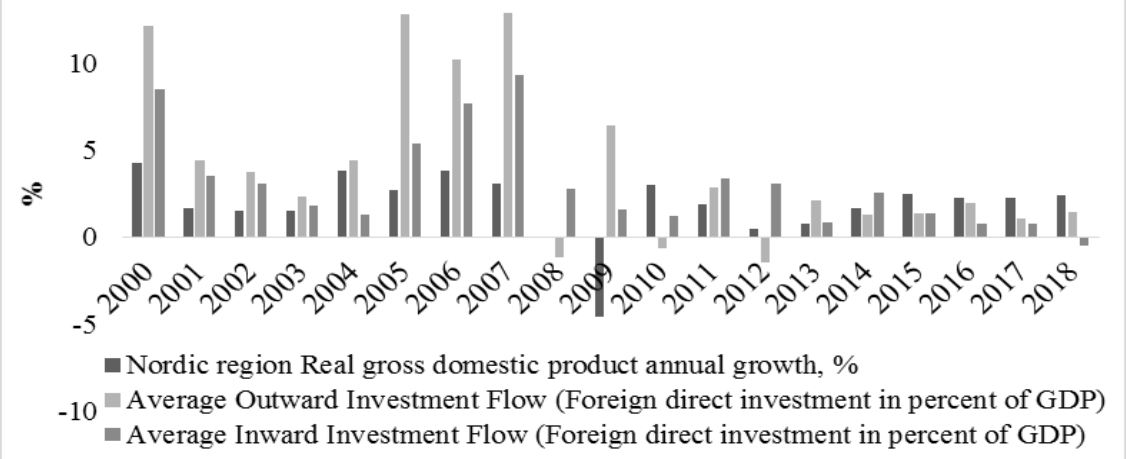

Source: Nordic co-operation (n./d.b, n./d.d).

A direct correlation between the net borrowing of the countries of the Nordic Region and the real growth of the GDP of the Nordic Region is also observed (Nordic cooperation, n./d.c; n./d.d). At the same time, net borrowing averaged $-0,3 \%$ in the Nordic region in 2000-2018: in Denmark: 0,7\% of GDP, in Finland 0,1\% of GDP, in Iceland $-1,7 \%$ of GDP, in Norway $0,04 \%$ of GDP, in Sweden 0,3\% of GDP (Nordic cooperation, n./d.a). Thus, due to borrowing, countries in the Nordic Region are less likely to finance development, while foreign investment is one of the main financing instruments. Funding indicators directly affect the level of economic growth in the Nordic region (Table 1).

The growth of real GDP in the Nordic region is related to the average level of inflow and outflow of foreign direct investment ( 0,36 and 0,28 , respectively), the average level of growth of net borrowing $(0,10)$. The Granger causality test indicates that the annual growth rate of real GDP in the Nordic region is a consequence of the inflow and outflow of direct investment from countries in this region (Table 2) with a period of 2 years. 
Table 1. Correlation matrix between Nordic region real GDP annual growth and countries' funding indicators

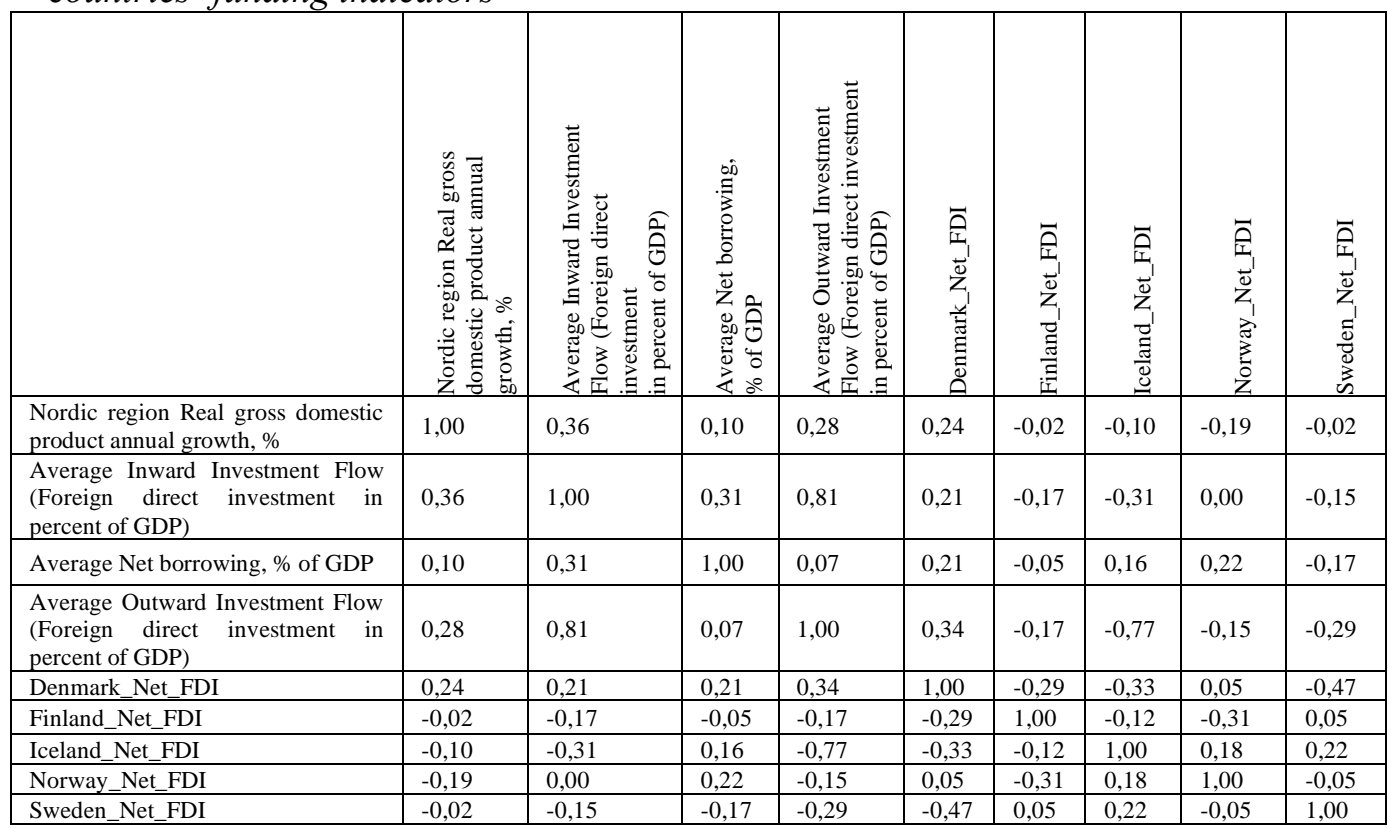

Source: Composed by the authors on the basis of Nordic co-operation (n./d.b, n./d.c, n./d.d).

Table 2. Pairwise Granger Causality Tests

\begin{tabular}{|l|l|l|l|}
\hline \multicolumn{2}{|l|}{ Pairwise Granger Causality Tests } & & \\
\hline Sample: 20002018 & Obs & F-Statistic & Prob. \\
\hline Lags: 2 & 17 & 2.99643 & $0.0880^{* *}$ \\
\hline Null Hypothesis: & 17 & 3.63022 & $0.0585^{* *}$ \\
\hline $\begin{array}{l}\text { Average Net borrowing does not Granger Cause Average Inward } \\
\text { Investment Flow }\end{array}$ & 17 & 5.92370 & $0.0162^{*}$ \\
\hline $\begin{array}{l}\text { Average Outward Investment Flow does not Granger Cause } \\
\text { Average Inward Investment Flow }\end{array}$ & 17 & 5.37798 & $0.0215^{*}$ \\
\hline $\begin{array}{l}\text { Average Net borrowing does not Granger Cause Average Outward } \\
\text { Investment Flow }\end{array}$ & 17 & $0.0398^{*}$ \\
\hline $\begin{array}{l}\text { Average Outward Investment Flow does not Granger Cause Nordic } \\
\text { region Real gross domestic product annual growth }\end{array}$ & 17 & 17.27003 & $\begin{array}{l}\text { Average Inward Investment Flow does not Granger Cause Nordic } \\
\text { region Real gross domestic product annual growth }\end{array}$ \\
\hline
\end{tabular}

Note: * p-value $<0.05$, ** p-value $<010$.

Source: Composed by the author on the basis of Nordic co-operation (n./d.b, n./d.c, n./d.d).

The activities of the Euroregions are ensured by the relevant profile Committee of the Regions at the level of European Union, which is the youngest of the European profile institutions forasmuch as it was established in 1994 under the Maastricht Treaty on European Union. The basic objective of its activity is to represent the interests of the local regional authorities of EU member states and ensure their participation in the integration process (The EU's Assembly of Regional and Local Representatives, n./d.). At the beginning of its activities, this committee was 
established as an advisory body to provide conclusions and recommendations at the request of EU Council of Ministers and EU Commission. In addition, the Committee of the Regions attaches great importance to the implementation of the principle of subsidiarity on its own initiative, according to which decisions should be taken at the level closest to the population and which can ensure their most effective implementation.

As a matter of practice, agreements on cross-border cooperation due to the formation of Euroregions, as a rule, are drawn up with the help of legal documents in the form of an optional cooperation agreement, private associations with a cross-border purpose, as well as instruments that provide legal capacity to the organization. Herewith, the regulation of the latter type is carried out on the basis of norms of private or public law (MOT, 2017). At the same time, the signed agreement on cooperation between territorial authorities is the most common among these types of legal documents (MOT, 2017). Such agreement represents obligations between the authorities of the member countries of the Euroregion on joint cross-border initiatives. There is no enforcement because it is primarily a political agreement between regional entities, and the degree of compliance with the norms specified in the agreement is usually based on political impulse and interpersonal relations.

In the case of private associations with a cross-border purpose, they have a more simplified organizational structure and are subject to regulation by private law. Such Euroregions may take the form of private non-profit associations or nongovernmental organizations. In this case, their activities will be regulated by the location of the headquarters or registered office of the organization (MOT, 2017).

The organizations are the final form of relations between the countries involved in the Euroregion; they are vested with legal capacity, and as a result, the ability to manage EU cross-border initiatives. However, Sanguin (2013) notes that the existence of such a wide range of legal frameworks for formalizing the relations between countries can create complexity and ambiguity, which can negatively affect their activities.

Currently, the most popular form of cross-border cooperation between regions is the European Grouping of Territorial Cooperation (EGTC), which functions as an autonomous and permanent structure endowed with legal capacity, and is also subject to regulation by the rules of public or private law in force at the location place of the organization's headquarters. Analysis of statistics shows that about 16 such organizations have been formed in the last decade.

Let's represent the structure of Euroregions according to use for the activity of the above-described forms of cooperation by means of Figure 3. Thus, from the Figure, we can see that the largest number of Euroregions choose cooperation agreements that are governed by public law (47\%). The second largest block of Euroregions coordinate their activities in the form of EGTC (28\%). At the same time, about $18 \%$ 
of Euroregions operate in the form of private associations, regulated by private law. Other forms of organization and regulation of relations account for $7 \%$.

Figure 3. The structure of Euroregions in the form of regulation of cooperation between them

Source: Durà et al. (2018).

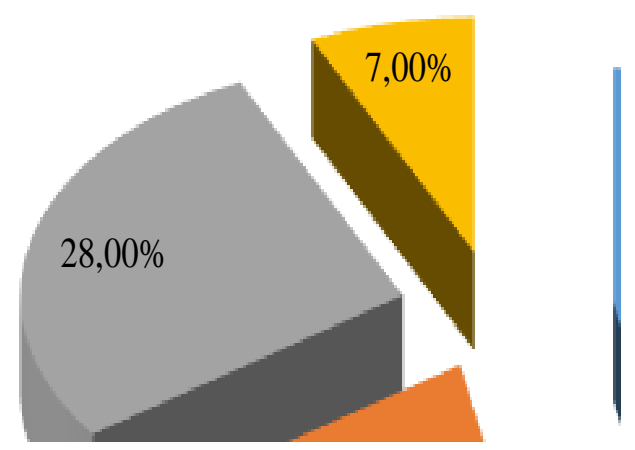

Another important aspect of stimulating the development of Euroregions is their financial support, which is usually provided through numerous programs and funds of EU and Council of Europe. Interreg program is one of such programs, developed in the mid-1980s, the purpose of which was to promote cross-border cooperation. The program continues to operate nowadays. Other funds, providing financing for cooperation between regions include the European Regional Cooperation Fund called FEDER, the European Social Fund (ESF) - its basic direction of funding is the fight against discrimination in the field of labor, (totally, about 70 million EUR were allocated) (Durà et al., 2018).

The current procedure for financing the programs and projects of the Euroregions, which has replaced the popular quota financing in 1990, suggests that European resources can only be an additional source of funds, and not the basic one. Therefore, projects and programs are funded by the principle of joint funding of all parties involved, which increases the interest of participants in the success of their implementation (Noferini et al., 2020). At the same time, the functioning of the Euroregions may stumble upon a number of problems that significantly affect hindering of their development. In particular, one of such problems is the lack of consensus between the member states of a particular Euroregion, which stems from their different historical past and cultural characteristics, as well as differentiated directions for further development.

Along with this, another fact that can significantly slow down the development of the Euroregion is the cooperation of countries with different levels of development within its framework, and, therefore, different opportunities in the field of financing joint projects, which ultimately can lead to a total absence of any projects and 
programs in which this Euroregion is a key participant. The interference in the planning and discussion of funding sources of international institutions, responsible for regulating the activities of Euroregions, may be the solution to this problem, including in terms of stimulating the implementation of projects through additional inflow of external funds. Another important factor hindering the development of the Euroregions is the lack of profitable proposals for all its member regions. Therefore, in order to solve this problem, we consider it necessary to also involve an external mediator in the discussion, who will take into account the interests of all participants.

\section{Discussion}

Based on the study conducted, it has been found that a special form of stimulating the development of border areas within the countries of the world is the coordination of their activities within the Euroregions. After all, the territorial location on the border between different countries is a significant deterrent in the development of such regions. At the same time, within the framework of this scientific investigation, we have determined that although the process of formation of Euroregions began in the middle of the last century, such form of organization of cross-border activities has become especially widespread only since 1990. Along with this, an evolution of interaction between the countries within the Euroregion had been taking place from a simple exchange of people and the implementation of cultural programs, to the implementation of large-scale projects that would include all spheres of life. In particular, the directions of projects' implementation may be as follows; healthcare, human mobility, research and development, education and training, environmental protection, infrastructure, transport and communications, environmental protection, rescue and security, as well as tourism and the environment.

The expansion of the areas of cooperation between the countries within the Euroregions took place along with the formation of an international legal framework for regulating their activities. The period of 1980-2000 was the most active in this process, during which the basic normative documents were adopted. At the same time, in the framework of this scientific investigation, we have determined that the legal forms of formation of Euroregions are the conclusion of a cooperation agreement, the establishment of private associations for cross-border purposes, as well as organizations endowed with legal capacity (EGTC). Analysis of statistical data has revealed that the most popular form is a cooperation agreement, which is subject to public law (47\%). In addition, $18 \%$ of Euroregions are formed in the form of private associations and $28 \%$ in the form of organizations vested with legal capacity.

\section{Conclusion}

The conducted study contains information on the need to stimulate cooperation between border regions through such a specific form of their interaction as the formation of Euroregions. In this connection, the coordination of the activities of 
individual countries' territories along the border can have a positive impact on the equalisation of disparities in their development, as well as create prospects and opportunities for their further growth, which puts the activities of Euroregions in a prominent place as a driving force for the development of the country as a whole. Based on the above mentioned, we have determined the historical chronology of the development of the Euroregions, which includes 4 stages, as well as outlined the types of cooperation within the Euroregion. In particular, it has been defined that the types of cooperation in the Euroregion vary depending on the source of initiation of cooperation, the level of their development and the direction.

In addition, it has been established that the activities of the Euroregions are subject to regulation by European legislation, the essential part of which was adopted in 19802000. However, in addition to the general legislation, the activities of the Euroregion, depending on the chosen legal form of activity, may be governed by the rules of public or private law of the country where its headquarters or office is located. Possible forms of activities include an optional cooperation agreement, private associations, as well as organizations with legal capacity. Each of the forms specified has its advantages and disadvantages. At the same time, it should be noted that the activities of the Euroregions face a number of problems that negatively affect the results of their activities. Such problems include, in particular, historical and cultural features, differences in development levels, and, consequently, in the possibilities of inflow financial resources in the regions, as well as the difference in the common goals of each of the participating countries of the Euroregions.

\section{References:}

Akimova, L., Khomiuk, N., Bezena, I., Lytvynchuk, I., Petroye, O. 2020. Planning of socioeconomic development of the territories (experience of European Union). International Journal of Management, 11(4), 567-568.

Association of European Border Regions. n./d. Available at: https://www.aebr.eu/en/index.php.

Cekhanovich, V.B. 2019. European experience in managing Euroregional cooperation. Economy and State, 8, 77-79.

Durà, A., Camonita, C., Berzi, M., Noferini, A. 2018. Euroregions, Excellence and Innovation across EU borders. A Catalogue of Good Practice. Department of Geography, UAB, Barcelona.

Euroregions. 2010. Multicultural interdisciplinary handbook. Available at: http://grial4.usal.es/MIH/euroregions/en/presentation.html.

Gretta, M., Otto, J. 2019. Euroregional multifunctionality and its importance in the activation of border areas. Comparative Economic Research. Central and Eastern Europe, 22, 108-110. https://doi.org/10.2478/cer-2019-0007.

Krätke, S. 2002. The regional impact of EU Eastern enlargement: A view from Germany. European Planning Studies, 10(5), 651-664.

Lepik, K.L. 2009. Euroregions as mechanism for strengthening cross-border cooperation in the Baltic Sea region. Trames Journal of the Humanities and Social Sciences, 13(3), 265-274. 
MOT. 2017. Working group on innovative solutions to cross border obstacles. Available at: http://www.espacestransfrontaliers.org/fileadmin/user_upload/REPORT_20170628_WG_on_Innovative _ Solutions_to_Cross-Border_Obstacles.pdf.

Noferini, A., Berzi, M., Camonita, F., Dura, A. 2020. Cross-border cooperation in the EU: Euroregions amid multilevel governance and re-territorialization. European Planning Studies, 28, 245-247. https://doi.org/10.1080/09654313.2019.1623973.

Nordic co-operation. n./d.a. Available at: https://www.norden.org/en.

Nordic co-operation. (n./d.b). Nordic Statistics. Available at: https://www.nordicstatistics.org/the-economy/.

Nordic co-operation. n./d.c. PUBS14: General government surplus, deficit and debt by reporting country, national accounts indicator, unit and time. Available at: https://www.nordicstatistics.org/nordic-sustainable-development-indicators/thenordic-welfare-model/.

Nordic co-operation. n./d.d. Real gross domestic product annual growth by reporting country and time. Available at:

https://pxweb.nordicstatistics.org/pxweb/en/Nordic\%20Statistics/Nordic\%20Statistics Economy_National\%20accounts/NAAC02.px/table/tableViewLayout2/?rxid=4bd 7ba15-3c4a-4793-8711-6db1fc878223.

Roper, S. 2007. Cross-border and local co-operation on the island of Ireland: An economic perspective. Political Geography, 26(5), 554-574.

Sanguin, A.L. 2013. Euroregions and other EU's cross-border organizations: The risk of confusion, redundancy, oversizing and entropy. A critical assessment. Annales. Series Historia Et Sociologia, 23(1), 155-164.

The EU's Assembly of Regional and Local Representatives. n./d.. Available at: http://www.cor.europa.eu/.

Zapletalová, J. 2005. Geography of the Polish - Czech borderland: the case of Euroregion Beskydy. EUROPA XXI, 13, 161-172. 